\title{
PENGARUH NON PERFORMING FINANCING, CAPITAL ADEQUACY RATIO, BEBAN OPERASIONAL PENDAPATAN OPERASIONAL DAN NET IMBALAN TERHADAP RETURN ON ASSETS (STUDI PADA BANK MAYBANK SYARIAH PERIODE 2012-2019)
}

\author{
Lely Awintasari $^{1}$, Maulida Nurhidayati ${ }^{2}$ \\ ${ }^{1,2}$ Institut Agama Islam Negeri Ponorogo \\ Email: 1elyawintasari130798@gmail.com ${ }^{1}$, nurhidayati@iainponorogo.ac.id ${ }^{2}$
}

\begin{abstract}
The purpose of this study is to analyze the influence of Non Performing Financing (NPF), Capital Adequacy Ratio (CAR), Operating Expenses operating income (BOPO) and Net Rewards (NI) ratio on Return On Assets of Maybank Syariah Bank. A bank's Return on Assets (ROA) is a ratio that shows the bank's success in making a profit. If the ROA obtained by a small bank as a result of the bank can suffer losses and hinder the growth of the bank. This research is a type of quantitative research with Error Correction Model method with a significance rate of 5\%, with a total of 32 samples in the form of quarterly data published by Bank Maybank Syariah in 2012-2019. The findings in this study are that NPF negatively affects ROA in the short term but NPF has no effect on ROA in the long run. CAR has no effect on ROA in the short term but CAR has a positive effect on ROA in the long run. BOPO in the short and long term negatively affects ROA. NI in the short and long term has no effect on ROA. Simultaneously NPF, CAR, BOPO and NI both short-term and long-term affect ROA simultaneously. The amount of influence exerted in the short term is $89.20 \%$ while in the long term it is $88.57 \%$. In order to increase ROA, Maybank Syariah Bank as much as possible to reduce the percentage of $N P F$ and BOPO and can increase the CAR owned.
\end{abstract}

Keywords: $R O A, N P F, C A R, B O P O, N I$

Abstrak: Tujuan penelitian ini adalah untuk menganalisis pengaruh rasio kuangan Non Performing Financing (NPF), Capital Adequacy Ratio (CAR), Beban Operasional Pendapatan Operasional (BOPO) dan Net Imbalan (NI) terhadap Return On Assets Bank Maybank Syariah. Return on Assets (ROA) suatu bank merupakan rasio yang menunjukkan keberhasilan bank dalam menghasilkan keuntungan. Apabila ROA yang diperoleh bank kecil akibatnya bank dapat mengalami kerugian serta menghambat pertumbuhan bank tersebut. Penelitian ini berjenis penelitian kuantitatif dengan metode Error Correction Model dengan tingkat signifikansi 5\%, dengan jumlah sampel sebanyak 32 yang berupa data triwulan yang dipublikasikan oleh Bank Maybank Syariah tahun 2012-2019. Temuan pada penelitian ini adalah NPF berpengaruh negatif pada ROA dalam jangka pendek tetapi NPF tidak berpengaruh pada ROA dalam jangka panjang. CAR tidak berpengaruh pada ROA pada jangka pendek namun CAR berpengaruh positif terhadap ROA dalam jangka panjang. BOPO dalam jangka pendek maupun jangka panjang berpengaruh negatif pada ROA. NI dalam jangka pendek maupun jangka panjang tidak berpengaruh pada ROA. Secara simultan NPF, CAR, BOPO dan NI baik jangka pendek maupun jangka panjang berpengaruh terhadap ROA secara simultan. Besarnya pengaruh yang diberikan pada jangka pendek adalah $89,20 \%$ sedangkan pada jangka panjang sebesar 88,57\%. Untuk dapat meningkatkan ROA, Bank Maybank Syariah sebisa 
mungkin untuk menurunkan persentase NPF dan BOPO serta dapat meningkatkan CAR yang dimiliki.

Kata Kunci: ROA, NPF, CAR, BOPO, NI

\section{PENDAHULUAN}

Krisis moneter yang mulai berjangkit pada pertengahan tahun 1997 berdampak sangat buruk bagi perekonomian Indonesia, termasuk industri perbankan yang semula sudah rapuh. Akibatnya pada November 1997 ada 16 bank konvensional yag dilikuidasi oleh Pemerintah yang berakibat turunya kepercayaan masyarakat pada bank konvensional yang menimbulkan terjadinya rush. Hal ini berakibat pada banyak bank yang collaps dan mengalami kesulitan likuiditas (Dendawijaya, 2005). Berbanding terbalik dengan apa yang dialami bank konvensional, bank syariah justru lebih tahan akan krisis moneter pada saat itu yang dibuktikan dengan Bank Muamalat menyalurkan pembiayaan 392 miliar rupiah naik menjadi 527 miliar rupiah pada tahun 1999 (Anggraini, AR, \& Saifi, 2015). Hal ini menunjukkan tingkat minat dan kepercayaan masyarakat pada perbankan syariah mengalami peningkatan dan sektor perbankan syariah mulai berkembang di Indonesia.

Seiring berjalanya waktu, perkembangan bank syariah di Indonesia terus meningkat. Pada bulan Juni 2020, asset bank syariah mencapai 545,39 triliun rupiah, Dana Pihak Ketiga (DPK) 430,21 triliun rupiah dan pembiayaan yang disalurkan 377,53 triliun rupiah. Untuk market share perbankan syariah Juni 2020 mencapai 6,18 \%. Jumlah ini masih kalah jauh bila dibandingkan dengan market share perbankan konvensional yang mencapai angka 32,17 \% sehingga untuk memperebutkan pasar perbankan di Indonesia, maka bank syariah dituntut mempunyai kinerja keuangan yang baik. Kinerja keuangan adalah gambaran kondisi keungan bank dari masa lalu dan sebagai prospek masa depan. Kondisi keungan pada suatu bank membutuhkan ukuran tertentu, alat pengukuran ini biasanya menggunakan analisis rasio keungan yang berfungsi sebagai cara paling umum serta paling mudah yang mengakibatkan analisis rasio keuangan ini paling banyak digunakan dalam pengukuran kinerja suatu bank (Muhammad, Khairul, \& Muhammad, 2020). Profitabilitas adalah indikator yang paling tepat untuk memperkirakan kinerja bank. Rasio ini berfungsi sebagai alat untuk membandingkan berbagai pilihan investasi berdasarkan tingkat resikonya. Semakin tinggi tingkat investasi semakin tinggi pengembaliannya.

Untuk melihat profitabilitas suatu bank maka dapat menggunkan salah satu rasionya yaitu Return on Assets (ROA) yang merupakan persentase yang paling sering 
dipakai karena dapat menunjukan keberhasilan bisnis yang menguntungkan. ROA menjadi ukuran bank untuk menghasilkan pendapatan dimasa lalu untuk dapat diproyeksikan pada masa depan(Nuraini \& Muttaqin, 2018).

Tabel 1. Rata-rata Return on Assets Bank Umum Syariah tahun 2012-2019

\begin{tabular}{clcclc}
\hline No & Bank & Rata-Rata & No & Bank & Rata-Rata \\
\hline 1 & $\begin{array}{l}\text { Bank Tabungan Pensiun } \\
\text { Nasional Syariah }\end{array}$ & 6,22 & 8 & Bank BRI Syariah & 0,55 \\
\hline 2 & $\begin{array}{l}\text { Bank Nusa Tenggara } \\
\text { Barat Syariah }\end{array}$ & 3,83 & 9 & Bank Syariah Bukopin & 0,39 \\
\hline 3 & Bank Aceh Syariah & 2,86 & 10 & Bank Muamalat Indonesia & 0,33 \\
\hline 4 & Bank Mega Syariah & 1,59 & 11 & Bank Panin Dubai Syariah & $-0,31$ \\
\hline 5 & Bank BNI Syariah & 1,44 & 12 & Bank Victoria Syariah & $-0,47$ \\
\hline 6 & Bank BCA Syariah & 1,04 & 13 & Bank Mayabank Syariah & $-1,31$ \\
\hline 7 & Bank Mandiri Syariah & 1,01 & 14 & $\begin{array}{l}\text { Bank BPD Jabar Banten } \\
\text { Syariah }\end{array}$ & $-1,42$ \\
\hline
\end{tabular}

Sumber: Laporan tahunan Bank Umum Syariah (2012-2019)

Tabel 1 memperlihatkan terdapat 3 bank yang memiliki rata-rata ROA paling kecil yakni Bank BPD Jabar Banten Syariah (-1,42 \%), Bank Maybank Syariah (-1,31 \%) serta Bank Victoria Syariah (-0,47\%).

Tabel 2 Return on Assets Bank Umum Syariah Periode 2012-2019

\begin{tabular}{|c|c|c|c|c|c|c|c|c|c|}
\hline \multirow{2}{*}{ No } & \multirow{2}{*}{ Bank } & \multicolumn{8}{|c|}{ Dalam (\%) } \\
\hline & & 2012 & 2013 & 2014 & 2015 & 2016 & 2017 & 2018 & 2019 \\
\hline 1 & Bank Victoria Syariah & 1,43 & 0,50 & $-1,87$ & -236 & -219 & 0,36 & 0,32 & 0,05 \\
\hline 2 & $\begin{array}{l}\text { Mayabank } \\
\text { h }\end{array}$ & 2,88 & 2,87 & 3,61 & $-20,13$ & $-9,51$ & 5,50 & $-6,86$ & 11,15 \\
\hline 3 & $\begin{array}{l}\text { Bank BPD Jabar } \\
\text { Banten Syariah }\end{array}$ & $-0,59$ & 0,91 & 0,72 & 0,25 & $-8,09$ & $-5,69$ & 0,54 & 0,60 \\
\hline
\end{tabular}

Sumber: Laporan tahunan Bank Umum Syariah (2012-2019)

Dilihat dari ketiga bank pada Tabel 2, ROA Bank Maybank Syariah adalah ROA yang paling banyak mengalami fluktuasi yang paling tajam. Hal ini dapat dilihat dari nilai ROA Bank Maybank Syariah pada tahun 2015 terjadi penurunan yang drastis yang mencapai -20,13 \%. Jika dibanding dengan ROA Bank BPD Jabar Banten Syariah dan Bank Victoria Syariah, perolehan ROA kedua bank tersebut juga mengalami fluktuasi namun tidak mengalami penurunan setajam ROA Maybank Syariah.

Melihat perolehan ROA Bank Maybank Syariah maka perlu adanya perhatian khusus, menimbang pentingnya ROA sebagai rasio yang dipakai memperkirakan 
kemampuan bank dalam memperoleh keuntungan. ROA dapat memperkirakan kemampuan perusahaan memperoleh keuntungan pada masa lampau untuk kemudian diproyeksikan pada masa mendatang. Perolehan ROA yang semakin besar mengakibatkan tingkat keuntungan atau laba yang dicapai bank menjadi semakin besar dan pula posisi bank tersebut dari segi penggunaan aset semakin baik (Dendawijaya, 2005).

Bank Indonesia akan memberikan nilai maksimum yaitu 100 (sehat) bank memiliki nilai ROA > 1,5\% (Arif \& Rahmawati, 2018). ROA Bank Maybank Syariah pada tahun 2015 dengan nilai sebesar -20,13\%, pada tahun 2016 sebesar $-9,51 \%$ dan pada tahun 2018 sebesar -6,86 \% menunjukkan bahwa ROA Bank Maybank Syariah masih jauh dari kriteria sehat dari apa yang telah ditetapkan Bank Indonesia. Maka dari itu perlu adanya peningkatan kinerja profitabilitas Bank Maybank Syariah dalam meningkatkan perolehan Return On Assets.

Ada dua faktor yang menetukan Return On Assets yakni faktor internal dan eksternal. Faktor eksternal merupakan faktor yang tidak dapat dikendalikan bank. Faktor ini meliputi persaingan, regulasi, konsentrasi, pangsa pasar, kepemilikan, kelangkaan modal, jumlah uang beredar, inflasi, tingkat suku bunga, nilai tukar valas, skala ekonomi dan ukuran bank. Faktor internal merupakan faktor yang berasal dari dalam dan dapat dikendalikan oleh bank. Faktor ini meliputi penghimpunan dana, manajemen modal, manajemen likuiditas, manajemen biaya dan semuanya yang dianggap dapat dikendalikan oleh bank(Ernayani, Moorcy, \& Sukimin, 2018). Analisis rasio keungan adalah salah satu faktor internal bank karena dianggap dapat dikontrol oleh manajemen bank untuk dijadikan sebagai rujukan pembuatan perencanaan, sebagai alat menilai kinerja dan prestasi bank, dan dapat dijadikan sebagai alat untuk menilai kondisi bank dari sudut pandang keungan (Fahmi, 2011, hlm. 47). Rasio keungan yang mempengaruhi profitabilitas (ROA) yakni Non Performing Financing (NPF), Capital Adequacy Ratio (CAR), Beban Operasional Pendapatan Operasional (BOPO) dan Net Imbalan (NI).

Tabel 3 memperlihatkan nilai NPF pada tahun 2015 mengalami kenaikan dari 5,04\% menjadi 35,15\% dan diikuti kenaikan ROA dari 3,61\% menjadi 4,50\%. Kondisi ini membuktikan ada kesenjangan antara informasi dengan teori. Dimana rasio NPF digunakan untuk memperkirakan kemampuan manajemen mengenai tingkat permasalahan pembiayaan, semkin tinggi NPF maka semakin rendah ROA bank tersebut. 
Hal ini karena bank tidak dapat membiayai aset produktif lainnya apabila dana tidak dapat ditagih (Ubaidillah, 2016).

Tabel 3. Rasio Keuangan Bank Maybank Syariah 2012-2019

\begin{tabular}{cccccc}
\hline Tahun & \multicolumn{5}{c}{ Dalam $(\%)$} \\
NPF & BOPO & CAR & NI & ROA \\
\hline 2012 & 2,49 & 53,77 & 63,89 & 5,78 & 2,88 \\
\hline 2013 & 2,69 & 67,79 & 59,41 & 5,61 & 2,87 \\
\hline 2014 & 5,04 & 69,60 & 52,13 & 6,65 & 3,61 \\
\hline 2015 & 35,15 & 69,62 & 38,40 & 6,54 & 4,50 \\
\hline 2016 & 43,99 & 192,00 & 55,60 & 4,99 & $-20,13$ \\
\hline 2017 & 0,00 & 160,28 & 75,83 & 8,79 & $-9,51$ \\
\hline 2018 & 0,00 & 199,97 & 163,87 & 18,28 & 5,50 \\
\hline 2019 & 0,00 & 84,70 & 241,84 & 9,94 & $-6,86$ \\
\hline
\end{tabular}

Sumber Laporan Keuangan Bank Maybank Syariah (2012-2019)

Nilai CAR pada tahun 2015 mengalami penurunan dari 52,13\% menjadi 38,40\% namun penurunan ini tidak diikuti oleh penurunan ROA, justru ROA mengalami kenaikan. Begitu pula pada tahun 2016 dimana CAR mengalami kenaikan dari 38,40\% menjadi 55,60\% serta tahun 2019 CAR juga mengalami kenaikan dari 163,87\% menjadi $241,84 \%$ namun ROA justru mengalami penurunan. Hal ini bertentangan dengan teori yang menyebutkan bahwa semakin tinggi CAR bank, maka kinerja bank semakin baik yang berujung pada meningkatnya profitabilitas atau ROA (Ubaidillah, 2016).

Selanjutnya rasio BOPO pada tahun 2015 mengalami kenaikan dari 69,60\% menjadi 69,62\% serta pada tahun 2018 juga mengalami kenaikan dari 160,28\% menjadi 199,97\% dan diikuti kenaikan ROA pada tahun 2015 dari 3,61\% menjadi 4,50\% dan tahun 2018 dari $-9,51 \%$ menjadi 5,50\%. Melihat fakta ini diketahui bahwa ada ketidak sesuaian teori dimana setiap peningkatan biaya operasional dapat menurunkan laba sebelum pajak, yang pada akhirnya dapat mengurangi laba atau ROA bank(Suwarno \& Muthohar, 2018).

Rasio Net Imbalan tahun 2015 mengalami penurunan dari 6,54\% menjadi 4,99\% dan ROA mengalami kenaikan dari 3,61\% menjadi 4,50\%. Menurut teori, semakin tinggi rasio NI maka pendapatan/ laba (ROA) yang diterima oleh bank semakin tinggi(Ramadhan, 2017). Kondisi ini membuktikan adanya perbedaan teori dan fakta yang ada.

Dari pemaparan data diketahui terdapat perbedaan antara teori dan fakta yang tercermin di dalam laporan keuangan Bank Maybank Syariah sehingga penelitian ini 
menarik untuk diteliti lebih lanjut menganai pengaruh NPF, CAR, BOPO dan NI terhadap ROA dengan menggunakan metode Error Correction Model.

\section{TINJAUAN LITERATUR}

\section{Return On Assets (ROA)}

Return On Assets (ROA) dipakai oleh manajemen bank untuk memperkirakan kemampuan bank dalam mencapai total return atau pengembalian atas total aset yang dimiliki. Rasio ROA yang semakin besar pada suatu bank menunjukkan bahwa tingkat keuntungan yang diperoleh bank juga semakin besar(Dendawijaya, 2005, hlm. 118). Dengan kata lain semakin rendah ROA berarti bank tidak memiliki kemampuan untuk mengelola aset mereka untuk dapat meningkatkan pendapatan dan menghemat biaya.

Return on Assets adalah persentase yang paling sering dipakai. Hal ini karena ROA dapat menandai keberhasilan bisnis yang menguntungkan. ROA dapat menjadi tolak ukur potensi perusahaan dalam menghasilkan keuntungan dimasa depan. Assets merupakan semua harta perusahaan yang didapatkan dari modal sendiri maupun modal asing yang sudah diubah perusahaan menjadi aktiva untuk selanjutnya dimanfaatkan oleh perusahaan. Semakin besar nilai pengembalian aset atau ROA semakin tinggi kinerja perusahaan. Hal ini mencerminkan bahwa semakin besar nilai ROA maka kinerja perusahaan juga semakin baik (Nuraini \& Muttaqin, 2018). Untuk menghitung ROA dapat digunakan rumus berikut:

$$
\mathrm{ROA}=\frac{\text { laba sebelum pajak }}{\text { Rata }- \text { rata total aset }} \times 100 \%
$$

\section{Non Performing Financing (NPF)}

Rasio Non Performing Financing (NPF) adalah rasio yang digunakan untuk memperkirakan risiko pembiayaan yang dialami bank akibat memberikan pembiayaan dan investasi dana bank pada portofolio yang berbeda. Semakin rendah nilai NPF yang dimiliki oleh suatu bank maka semakin rendah risiko pembiyaan yang ditanggung pihak bank. Artinya, bank yang memiliki NPF tinggi menggabarkan bank tersebut tidak mampu mengelola pembiayaan yang dimiliki, serta mengndikasikan bahwa tingkat risiko atau pemberian pembiayaan pada bank tersebut cukup tinggi searah dengan tingginya NPF yang dihadapi bank (Ubaidillah, 2016). NPF dapat dirumaskan sebagai berikut (Ubaidillah, 2016): 


$$
\mathrm{NPF}=\frac{\text { Pembiyaan Bermaslah }}{\text { Total Pembiayaan }} \times 100 \%
$$

\section{Capital Adequacy Ratio (CAR)}

Capital Adequacy Ratio (CAR) atau rasio kecukupan modal merupakan rasio yang digunakan untuk menentukan bagaimana suatu bank mampu menggunakan kepemilikan modalnya untuk membiayai aktivitas kegiatannya. CAR merupakan rasio kinerja suatu bank yang digunakan untuk memperkirakan kecukupan modal bank dalam menunjang aktiva yang mengandung atau menghasilkan risiko. Jika CAR yang dimiliki bank lebih tinggi maka bank mempunyai kinerja yang baik karena dapat membiayai operasi bank atau dapat menangani resiko yang mungkin timbul (Zulifiah \& Susilowibowo, 2014). Untuk menghitung CAR dapat digunakan rumus berikut (Dendawijaya, 2005) :

$$
\text { CAR }=\frac{\text { Modal }}{\text { Aktiva Tertimbang Menurut Risiko }} \times 100 \%
$$

\section{Biaya Operasional Pendapatan Operasional (BOPO)}

Rasio Biaya Operasional Pendapatan Operasional atau BOPO adalah rasio beban operasional terhadap pendapatan operasional yang digunakan untuk memperkirakan tingkat kinerja dan efisiensi suatu bank (Dendawijaya, 2005). Setiap penambahan biaya operasional dapat mengurangi keuntungan sebelum pajak sehingga keuntungan atau profitabilitas (ROA) bank akan mengakanu penurunan (Suwarno \& Muthohar, 2018). Perumusan BOPO sebagai berikut(Dendawijaya, 2005):

$$
\text { BOPO }=\frac{\text { Beban Oprasional }}{\text { Pendapatan Oprasional }} \times 100 \%
$$

\section{Net Imbalan (NI)}

NI atau Net Imbalan adalah rasio yang dipakai untuk memahami kemampuan aktiva produktif suatu bank dalam mendatangkan keuntungan atau laba dengan cara membandingkan pendapatan operasional dikurangi dengan imbalan dan bonus rata-rata aktiva produktif. NI merupakan ukuran spread atau gross margin dari aktiva kredit dan investasi dari bank (Ramadhan, 2017). Rasio NI ini dapat menunjukkan seberapa besar 
tingkat efisiensi bank dalam mengelola aktiva produktifnya. Perhitungan rasio NI sebagai berikut:

$$
N I=\frac{\text { Pendaptan Penyaluran Dana setelah Bagi Hasil }- \text { (Imbalan dan Bonus) }}{\text { Rata }- \text { rata Aktiva Produktif }} \times 100 \%
$$

\section{METODE PENELITIAN}

Penelitian ini merupakan penelitian kuantitatif dengan metode analisis yang digunakan adalah Error Correction Model (ECM). Jumlah sampel yang dilibatkan dalam penelitian ini adalah 32 yang merupakan data triwulan yang diterbitkan oleh Bank Maybank Syariah dari tahun 2012 hingga tahun 2019. Metode pengambilan sampling dilakukan dengan teknik sampling purposive yang merupakan teknik pengambilan sempel dengan pertimbangan tertentu (Sugiono, 2014). Teknik pengumpulan datanya dilakukan dengan mengumpulkan Laporan Keuangan Bank Maybank Syariah Tahun 2012-2019. Penelitian ini menggunakan variabel independen pada penelitian NPF, CAR, BOPO dan NI serta ROA sebagai variabel dependen.

\section{HASIL DAN PEMBAHASAN}

\section{Uji Stasioneritas Data}

Uji stasioneritas dilakukan untuk memastikan variabel independent dan dependen stasioner dalam mean. Pengujian stasioneritas menggunakan uji ADF (Augmented Dickey-Fuller) pada tingkat level dan first difference.

Tabel 4. Hasil Pengujian Stasioneritas dengan ADF

\begin{tabular}{ccccc}
\hline \multirow{2}{*}{ Variabel } & \multicolumn{2}{c}{ Level } & \multicolumn{2}{c}{ Fisrt Difference } \\
\cline { 2 - 5 } & t-hitung & Sig & t-hitung & Sig \\
\hline ROA & $-2,557$ & 0,1125 & $-7,981$ & 0,000 \\
\hline NPF & $-2,088$ & 0,2504 & $-5,926$ & 0,000 \\
\hline CAR & 0,828 & 0,9929 & $-4,591$ & 0,000 \\
\hline BOPO & $-3,126$ & 0,0349 & $-7,838$ & 0,000 \\
\hline NI & $-1,927$ & 0,3160 & $-7,146$ & 0,000 \\
\hline
\end{tabular}

Sumber: Data diolah (2021)

Hasil pada Tabel 4 menunjukkan bahwa hanya BOPO yang stasioner pada tingkat level sehingga dilakukan pengujian pada tingkat first difference. Hasil pengujian menunjukkan bahwa ROA, NPF, CAR, BOPO, dan NI stasioner pada tingkat first difference. 


\section{Uji Kointegrasi}

Tabel 5. Hasil Pengujian Kointegrasi

\begin{tabular}{cc}
\hline t-hitung & Sig \\
\hline$-4,1801$ & 0,0027 \\
\hline
\end{tabular}

Sumber: Data diolah (2021)

Uji Kointegrasi dilakukan setelah semua variabel memiliki orde stasioner. Uji kointegrasi Engle Granger pada Tabel 5 menunjukkan bahwa uji kointegrasi terpenuhi karena nilai sig $=0,0027$.

\section{Uji Asumsi Klasik Model Hubungan Jangka Pendek}

Uji asumsi klasik dilakukan pada model hubungan jangka pendek. Pengujian asumsi klasik meliputi uji normalitas, uji heteroskedastisitas, uji autokorelasi, dan uji multikolinieritas.
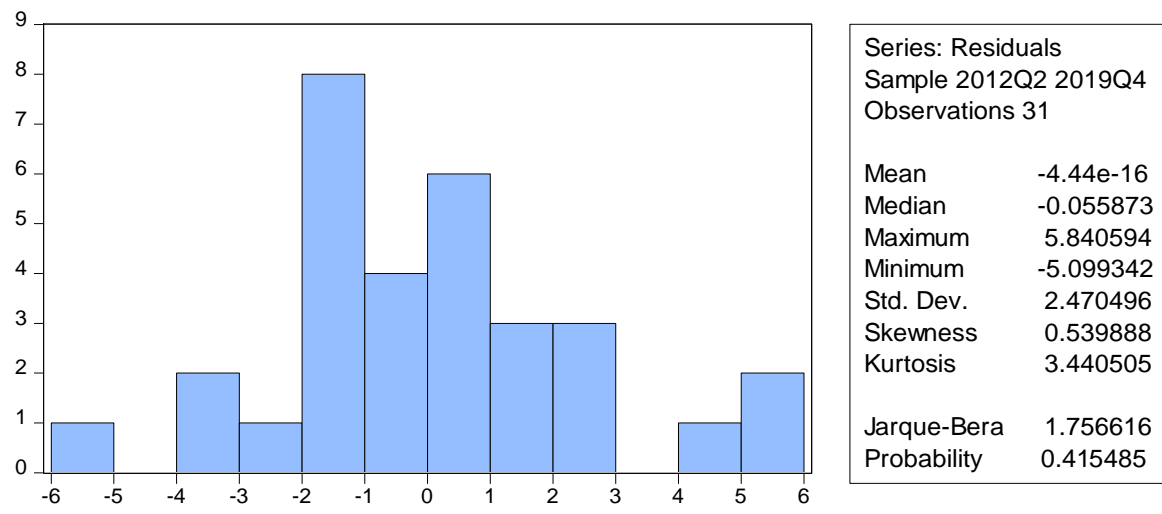

Gambar 1. Pengujian Normalitas

Uji normalitas Pada Gambar 1 dilakukan dengan metode Jarque-Bera. Hasil tersebut menunjukkan bahwa nilai Jarque-Bera $=1,756616<5,99$ sehingga asumsi normalitas terpenuhi.

Tabel 6. Hasil Pengujian Heteroskedastisitas

\begin{tabular}{|c|c|c|c|}
\hline F-hitung & 0,86856 & Sig. F(5,25) & 0,5160 \\
\hline Obs $* \mathrm{R}^{2}$ & 4,58807 & Sig. $\chi^{2}(5)$ & 0,4682 \\
\hline Scaled explained SS & 4,31234 & $\operatorname{Sig} \chi^{2}(5)$ & 0,5054 \\
\hline
\end{tabular}

Uji heteroskedastisitas pada Tabel 6 menggunakan uji Glejser. Hasil perhitungan menunjukkan bahwa nilai signifikansi dari $\chi^{2}$ untuk Obs* $R^{2}$ adalah $0,4682>0,05$ sehingga asumsi non heteroskedastisitas terpenuhi. Uji autokorelasi dengan Breusch Godfrey Serial Correlation LM test pada Tabel 7 menunjukkan bahwa nilai probabilitas dari $\chi^{2}$ untuk Obs* $\mathrm{R}^{2}$ adalah $0,6137>0,05$ sehingga asumsi non autokorelasi terpenuhi. 
Tabel 7. Hasil Pengujian Autokorelasi

\begin{tabular}{llll}
\hline F-hitung & 0,374077 & Sig. $F(2,23)$ & 0,6920 \\
\hline Obs* $\mathrm{R}^{2}$ & 0,976613 & Sig. $\chi^{2}(2)$ & 0,6137 \\
\hline
\end{tabular}

Sumber: Data Sekunder Diolah(2021)

Tabel 8. Hasil Pengujian Autokorelasi

\begin{tabular}{cccc}
\hline \multirow{2}{*}{ Variable } & Coefficient & Uncentered & Centered \\
\cline { 2 - 4 } & Variance & VIF & VIF \\
\hline $\mathrm{C}$ & 0,265 & 1,122 & NA \\
\hline $\mathrm{D}(\mathrm{NPF})$ & 0,003 & 1,094 & 1,094 \\
\hline $\mathrm{D}(\mathrm{CAR})$ & $8,09 \mathrm{E}-08$ & 1,424 & 1,316 \\
\hline $\mathrm{D}(\mathrm{BOPO})$ & $1,68 \mathrm{E}-08$ & 1,673 & 1,673 \\
\hline $\mathrm{D}(\mathrm{NI})$ & 0,026 & 1,337 & 1,335 \\
\hline $\mathrm{EC}(-1)$ & 0,033 & 1,109 & 1,109 \\
\hline
\end{tabular}

Sumber: Data Sekunder Diolah(2021)

Uji multikolinieritas dengan Variance Inflation Factor (VIF) pada Tabel 8 menunjukkan bahwa nilai VIF semua variabel independent lebh dari 10 sehingga asumsi multikolinieritas terpenuhi.

\section{Model Hubungan Jangka Pendek}

Tabel 9. Model Hubungan Jangka Pendek

\begin{tabular}{ccccc}
\hline Variabel & Koefisien & SE & t-hitung & Sig \\
\hline C & 0,181189 & 0,514923 & 0,351876 & 0,7279 \\
\hline D(NPF) & $-0,151186$ & 0,051218 & $-2,951,811$ & 0,0068 \\
\hline D(CAR) & 0,000159 & 0,000285 & 0,559831 & 0,5806 \\
\hline D(BOPO) & $-0,001243$ & 0,000130 & $-9,592,752$ & 0,0000 \\
\hline D(NI) & 0,079899 & 0,160641 & 0,497376 & 0,6233 \\
\hline ECT(-1) & $-0,754052$ & 0,182769 & $-4,125,722$ & 0,0004 \\
\hline
\end{tabular}

Sumber: Data diolah (2021)

Model jangka pendek yang diperoleh dari Tabel 9 dapat dituliskan pada persamaan berikut

$$
\begin{gathered}
\Delta \mathrm{ROA}_{t}=0,81189-0,51186 \Delta \mathrm{NPF}_{t}+0,000159 \Delta \mathrm{CAR}_{t}-0,001243 \Delta \mathrm{BOPO}_{t} \\
+0,079899 \Delta \mathrm{NI}_{t}-0,754052 \mathrm{ECT}_{t-1}
\end{gathered}
$$

Berdasarkan persamaan tersebut dan hasil uji t, temuan penelitian sebagai berikut

a. $\triangle \mathrm{NPF}$ dengan nilai $\mathrm{t}_{\text {hitung }}=-2,951811<-2,0556$ artinya $\triangle \mathrm{NPF}$ berpengaruh pada $\triangle$ ROA. Koefisien $\triangle$ NPF sebesesar $-0,51186$ mengindikasikan bahwa peningkatan $\triangle \mathrm{NPF}$ diikuti oleh penurunan $\triangle \mathrm{ROA}$ yang artinya $\triangle \mathrm{NPF}$ memiliki pengaruh yang negatif dan signifikan pada $\triangle$ ROA. Lebih jauh, jika $\triangle$ NPF mengalami kenaikan $1 \%$ 
maka $\triangle \mathrm{ROA}$ akan mengalami penurunan sebesar $0,51186 \%$ dengan asumsi variabel yang lain tetap.

b. $\triangle \mathrm{CAR}$ dengan nilai $\mathrm{t}_{\text {hitung }}=0,559831>2,0556$ artinya $\triangle \mathrm{CAR}$ tidak berpengaruh pada $\triangle \mathrm{ROA}$.

c. $\triangle \mathrm{BOPO}$ dengan nilai $t_{\text {hitung }}=-9,592752<-2,0556$ artinya $\triangle \mathrm{BOPO}$ berpengaruh pada $\triangle$ ROA. Koefisien $\triangle B O P O$ sebesesar $-0,001243$ mengindikasikan bahwa peningkatan $\triangle \mathrm{BOPO}$ diikuti oleh penurunan $\triangle \mathrm{ROA}$ yang artinya $\triangle \mathrm{BOPO}$ berpengaruh negatif dan signifikan pada $\triangle R O A$. Lebih jauh, jika $\triangle B O P O$ mengalami kenaikan $1 \%$ maka $\triangle \mathrm{ROA}$ akan turun $0,001243 \%$ dengan mengasumsikan bahwa variabel yang lain dalam model tidak berubah.

d. $\Delta$ NI dengan nilai $t_{\text {hitung }}=0,497376>2,0556$ artinya $\Delta$ NI tidak berpengaruh terhadap $\triangle \mathrm{ROA}$.

Tabel 10. Uji Simultan Model Hubungan Jangka Pendek

\begin{tabular}{cc}
\hline F-hitung & Sig \\
\hline 41,28664 & 0,000000 \\
\hline
\end{tabular}

Sumber: Data diolah (2021)

Tabel 10 memperlihatkan nilai $\operatorname{Sig}=0,000<0,05$ yang artinya $\triangle \mathrm{NPF}, \triangle \mathrm{CAR}$, $\triangle \mathrm{BOPO}$ dan $\Delta \mathrm{NI}$ secara simultan memiliki pengaruh jangka pendek yang signifikan pada $\triangle$ ROA. Besarnya kontribusi yang diberikan oleh keempat variabel pada $\triangle \mathrm{ROA}$ adalah $89,2 \%$ sisanya $10,8 \%$ merupakan kontribusi variabel lain diluar model.

\section{Model Hubungan Jangka Panjang}

Model persamaan jangka panjang yang diperoleh dari Tabel 11 dapat dituliskan pada persamaan berikut

$$
\begin{gathered}
\mathrm{ROA}_{t}=10,83342-0,044832 \mathrm{NPF}_{t}+0,000418 \mathrm{CAR}_{t}-0,001292 \mathrm{BOPO}_{t} \\
-0,0353598 \mathrm{NI}_{t}+\mathrm{ECT}
\end{gathered}
$$

Tabel 11. Koefisien Model Hubungan Jangka Panjang

\begin{tabular}{ccccc}
\hline Variabel & Koefisien & SE & t-hitung & Sig \\
\hline C & 10,83342 & 1,731148 & 6,257942 & 0,0000 \\
\hline NPF & $-0,044832$ & 0,052554 & $-0,853066$ & 0,4011 \\
\hline CAR & 0,000418 & 0,000122 & 3,420993 & 0,0020 \\
\hline BOPO & $-0,001292$ & 0,000141 & $-9,191016$ & 0,0000 \\
\hline NI & $-0,035398$ & 0,143045 & $-0,247462$ & 0,8064 \\
\hline
\end{tabular}

Sumber: Data diolah (2021) 
Berdasarkan persamaan tersebut dan hasil uji t, temuan penelitian sebagai berikut

a. NPF dengan nilai $t_{\text {hitung }}=-0,853066>-2,0518$ artinya NPF tidak berpengaruh pada ROA.

b. CAR dengan nilai $t_{\text {hitung }}=3,420993>2,0518$ artinya CAR berpengaruh pada ROA. Koefisien CAR sebesesar 0,000418 mengindikasikan bahwa peningkatan CAR diikuti oleh peningkatan ROA yang artinya CAR berpengaruh positif dan signifikan pada ROA. Lebih jauh, jika CAR naik 1\% maka ROA naik 0,000418\% dengan mengasumsikan bahwa variabel yang lain dalam model tidak berubah.

c. BOPO dengan nilai thitung=-9,191016<-2,0518 artinya BOPO berpengaruh pada ROA. Koefisien BOPO sebesesar -0,001292 mengindikasikan bahwa peningkatan BOPO diikuti oleh penurunan ROA yang artinya BOPO berpengaruh negatif dan signifikan pada ROA. Lebih jauh, jika BOPO naik 1\% maka ROA turun 0,001292\% dengan dengan mengasumsikan bahwa variabel yang lain dalam model tidak berubah.

d. $\Delta$ NI dengan nilai $t_{\text {hitung }}=-0,247462>-2,0518$ artinya NI tidak berpengaruh pada ROA.

Tabel 12. Hasil Uji Simultan Model Hubungan Jangka Panjang

\begin{tabular}{cc}
\hline F-hitung & Sig \\
\hline 52,31896 & 0,000000
\end{tabular}

Sumber: Data diolah (2021)

Tabel 12 memperlihatkan nilai $\mathrm{Sig}=0,000<0,05$ yang artinya NPF, CAR, BOPO dan NI secara simultan memiliki pengaruh jangka panjang yang signifikan terhadap ROA. Besarnya pengaruh yang diberikan oleh keempat variabel tersebut adalah $88,57 \%$ sedangkan sisanya sebesar $11,43 \%$ dipengaruhi oleh variabel lain diluar model.

\section{Pengaruh NPF terhadap ROA}

Berdasarkan hasil pengujian model hubungan jangka pendek diketahui bahwa NPF berpengaruh negatif pada ROA yang didukung oleh beberapa penelitian yang dilakukan oleh Almunawwaroh dan Marliana(Almunawwaroh \& Marliana, 2018) serta Penelitian Yuwita Ariessa Pravasanti (Pravasanti, 2018). Suatu bank kehilangan kesempatan untuk mendapatkan penghasilan yang berasal dari pembiayaan yang diberikan dikarenakan banyaknya pembiayaan bermasalah yang mengakibatkan aktiva produktifnya lebih rendah dibandingkan pembiayaan bermasalah. 
NPF pada pengujian model hubungan jangka panjang tidak berpengaruh pada ROA yang senada dengan penelitian Muhammad Yusuf Wibisono dan Salamah Wahyuni(Wibisono \& Wahyuni, 2017). Hal ini dimungkinkan karena perolehan NPF Bank Maybank Syariah selama tahun 2017 hingga tahun 2019 tetap yakni sebesar 0,00\% yang menujukan bahwa selama tahun tersebut perubahan nilai ROA Bank Maybank Syariah tidak dipengaruhi oleh NPF. Meskipun NPF dalam pengujian model jangka panjang tidak berpengaruh pada ROA, namun Bank Maybank Syariah berhati-hati dalam mengelola dan menyalurkan pembiayaan.

\section{Pengaruh CAR terhadap ROA}

Dalam pengujian hubungan jangka pendek, CAR tidak berpengaruh pada ROA yang didukung oleh penelitian Yuwita Ariessa Pravasanti (Pravasanti, 2018) serta penelitian Muhammad Yusuf Wibisono dan Salamah Wahyuni(Wibisono \& Wahyuni, 2017). Hasil ini menunjukan bahwa kecukupan modal bank (CAR) yang besar atau kecil tidak selalu berakibat pada besar atau kecilnya keuntungan yang didapatkan oleh bank (ROA). Bank dengan modal yang cukup besar tidak selalu bisa memanfaatkan dan memakai modalnya dengan tepat untuk memperoleh penghasilan sehingga modal yang dimiliki tidak dapat mempengaruhi ROA bank tersebut. Selain itu, minimal kecukupan modal bank (CAR) sebesar $8 \%$ berdasarkan pada peraturan yang dikeluarkan Bank Indonesia ini menjadikan CAR tidak lagi berpengaruh kepada ROA dari bank.

CAR pada uji model hubungan jangka panjang berpengaruh positif pada ROA yang didukung oleh penelitian Nisa Friskana Yundi dan Heri Sudarsono (Yundi \& Sudarsono, 2018). Kecukupan modal bank (CAR) yang tinggi dapat meningkatkan kepercayaan masyarakat pada bank sehingga meskipun pada jangka pendek CAR tidak berpengaruh terhadap ROA akan tetapi CAR yang tinggi dan dalam jangka yang panjang tetap dibutuhkan oleh bank untuk meningkatkan kepercayaan masyarakat yang secara tidak langsung dapat memberikan keuntungan (ROA) pada bank.

\section{Pengaruh BOPO terhadap ROA}

Model hubungan jangka pendek dan jangka panjang menunjukkan bahwa BOPO berpengaruh negatif pada ROA yang didukung oleh penelitian Usman Harun (Harun, 2016) dan Rima Cahya Suwarno dan Ahmad Mifdlol Muthohar (Suwarno \& Muthohar, 2018) BOPO menunjukkan kemampuan suatu bank dalam mengelola biaya operasional 
yang dikeluarkan sehingga semakin kecil nilai BOPO menunjukkan bahwa bank dapat menggunakan dana yang dimiliki untuk kegiatan operasional dengan tepat dan proporsional. Hal ini menunjukkan bahwa semakin kecil nilai BOPO dapat meningkatkan keuntungan bank serta menunjukkan bahwa bank berada dalam kondisi yang baik dan tidak terjadi masalah didalamnya.

\section{Pengaruh NI terhadap ROA}

Pengujian model hubungan jangka pendek dan jangka panjang menunjukkan bahwa NI tidak berpengaruh pada ROA seperti penelitian yang dilakukan oleh Nissa Nabilla Alamsyah Putri (Putri, 2020) dan Pipit Savitri (Savitri, 2020). Hal ini karena komponen pendapatan bank dari NI yaitu pendapatan operasional bank dikurangi dengan imbalan dan bonus rata-rata aktiva produktif yang yang diperoleh bank. NI mampu menggambarkan profitabilitas yang lebih konkrit karena rasio ini benar-benar melihat seberapa besar penyaluran pembiayaan mampu menghasilkan pendapatan yang telah dikurangi beban imbalan bagi hasil. Dalam kondisi penuh persaingan seperti sekarang ini bank cenderung lebih berhati-hati dalam melakukan pemberian pembiayaan sehingga naik turunya ROA tidak dipengaruhi oleh NI. Namun Bank Maybank Syariah harus tetap berhati-hati dalam memberikan pembiayaan agar membuat kualitas aktiva produktifnya tetap terjaga. Dengan kualitas aktiva produktif yang bagus dapat meningkatkan pendapatan bunga bersih sehingga pada akhirnya berpengaruh terhadap meningkatnya ROA Bank Maybank Syariah.

\section{KESIMPULAN}

Berdasarkan penelitian ini diketahui bahwa NPF pada jangka pendek berpengaruh negatif pada ROA tetapi pada jangka panjang justru tidak ditemukan pengaruh yang signifikan. Untuk variabel CAR diperoleh hasil bahwa CAR pada jangka pendek tidak ditemukannya pengaruh pada ROA akan tetapi pada jangka panjang, CAR memberikan pengaruh positif pada ROA. BOPO pada jangka Panjang maupun pendek maupun jangka Panjang berpengaruh negative pada ROA serta NI pada jangka panjang maupun pendek maupun jangka panjang tidak berpengaruh pada ROA. Hasil ini mengindikasikan bahwa Bank Maybank Syariah harus memperhatikan beberapa rasio keuangan untuk dapat meningkatkan ROA yang dimiliki. Untuk dapat meningkatkan ROA, Bank Maybank Syariah dapat mulai memperhatikan perolehan NPF pada jangka Panjang, CAR pada 
jangka panjang serta BOPO pada jangka pendek dan jangka Panjang. Bank Maybank Syariah dapat meningkatkan ROA dengan cara menurunkan persentase NPF dan BOPO serta meningkatkan CAR yang dimiliki.

Pada penelitian ini, variabel independent yang digunakan masih fokus pada rasio keuangan bank sehingga pada peneliti selanjutnya diharapkan mampu mengembangkan analisis dari segi variabel independennya dengan menggunakan faktor internal maupun faktor eksternal bank. Selain dari segi variabel yang digunakan, penelitian lebih lanjut dapat dikembangkan dengan menggunakan analisis yang berbeda dengan penelitian ini.

\section{REFERENSI}

Almunawwaroh, M., \& Marliana, R. (2018). Pengaruh CAR, NPF dan FDR terhadap profitabilitas bank syariah di Indonesia. Amwaluna: Jurnal Ekonomi Dan Keuangan Syariah, 2(1), 1-17.

Anggraini, M., AR, Moch. D., \& Saifi, M. (2015). ANALISIS KINERJA KEUANGAN BANK KONVENSIONAL DAN BANK SYARIAH DENGAN MENGGUNAKAN PENDEKATAN RGEC (Studi pada PT. BRI, Tbk dan PT. BRI Syariah Periode 2011-2013). Jurnal Administrasi Bisnis (JAB), 27(1), 1-6.

Arif, M. N. R. A., \& Rahmawati, Y. (2018). Manajemen Resiko Perbankan Syariah. Bandung: Pustaka Setia.

Dendawijaya, L. (2005). Manajemen Perbankan. Bogor: Ghalia Indonesia.

Ernayani, R., Moorcy, N. H., \& Sukimin, S. (2018). Faktor-Faktor Yang Mempengaruhi Return On Assets (Studi Pada Bank Umum Syariah Di Indonesia Periode 20112016). UNEJ e-Proceeding, 284-293.

Fahmi, I. (2011). Analisis kinerja keuangan: Panduan bagi akademisi, manajer, dan investor untuk menilai dan menganalisis bisnis dari aspek keuangan. Bandung: Alfabeta.

Harun, U. (2016). Pengaruh Ratio-ratio Keuangan Car, Ldr, Nim, Bopo, Npl Terhadap Roa. Jurnal Riset Bisnis dan Manajemen, 4(1), 67-82.

Muhammad, S., Khairul, A., \& Muhammad, A. (2020). Kinerja Keuangan Bank Syariah Dengan Asset Quality, Earnings, Liquity dan Sharia Conformity. Depok: PT Raja Grafindo Persada.

Nuraini, \& Muttaqin, A. (2018). Korelasi Antara Penerapan Akad Mudharabah dan Profitabilitas Pada Bank Syariah Mandiri (Tahun 2012-2016). Falah Jurnal Ekonomi Syariah, 3(1), 26-37.

Pravasanti, Y. A. (2018). Pengaruh NPF dan FDR Terhadap CAR dan Dampaknya Terhadap ROA Pada Perbankan Syariah Di Indonesia. Jurnal Ilmiah Ekonomi Islam, 4(03), 148-159.

Putri, N. N. A. (2020). Pengaruh Net Imbalan (NI) dan Net Operating Margin (NOM) terhadap Return on Assets (ROA): Studi di Pt. Bank Panin Syariah, Tbk. periode 2016-2018 (PhD Thesis). UIN Sunan Gunung Djati Bandung. 
Ramadhan, A. A. (2017). PENGARUH RASIO TINGKAT KESEHATAN BANK TERHADAPPERTUMBUHAN LABA BANK UMUM SYARIAH DI INDONESIA. UNIVERSITAS ISLAM NEGERI SYARIF HIDAYATULLAH.

Savitri, P. (2020). Pengaruh Financing to Deposit Ratio (FDR) dan Net Imbalan (NI) terhadap Return On Asset (ROA) pada Bank Syariah Bukopin periode 2016-2018 (PhD Thesis). UIN Sunan Gunung Djati Bandung.

Sugiono. (2014). Metode Penelitian Kuantitatif Kualitatif dan $R \& D$. Bandung: Alfabeta. Suwarno, R. C., \& Muthohar, A. M. (2018). Analisis Pengaruh NPF, FDR, BOPO, CAR, dan GCG terhadap Kinerja Keuangan Bank Umum Syariah di Indonesia Periode 2013-2017. 6(1), 94-117.

Ubaidillah. (2016). Analisis Faktor-Faktor Yang Mempengaruhi Profitabilitas Bank Syariah di Indonesia. Jurnal Ekonomi Islam (Islamic Economics Journal), 4(1), 151-188.

Wibisono, M. Y., \& Wahyuni, S. (2017). Pengaruh Car, Npf, Bopo, Fdr, Terhadap Roa Yang Dimediasi Oleh Nom. Jurnal Bisnis dan Manajemen (Journal of Business and Management), 17(1), 41-62.

Yundi, N. F., \& Sudarsono, H. (2018). Pengaruh Kinerja Keuangan Terhadap Return on Asset (ROA) Bank Syariah di Indonesia. Al-Amwal: Jurnal Ekonomi dan Perbankan Syari'ah, 10(1), 18-31.

Zulifiah, F., \& Susilowibowo, J. (2014). Pengaruh inflasi, Bi Rate, Capital Adequacy Ratio (CAR), Non Performing Finance (NPF), Biaya Operasional dan Pendapatan Operasional (BOPO) terhadap profitabilitas Bank Umum Syariah Periode 20082012. Jurnal Ilmu Manajemen, 2(1), 759-770. 